\title{
BRAIN-DERIVED NEUROTROPHIC FACTOR (BDNF) SERUM AND INTELLIGENCE LEVELS OF ELEMENTARY SCHOOL CHILDREN IN RURAL AREAS, SELUMA REGENCY
}

\author{
Rostika Flora, ${ }^{1 *}$ Ena Juhaina, ${ }^{1}$ Ahmad Fickry Faisya, ${ }^{1}$ \\ Nur Alam Fajar, ${ }^{1}$ Yeni Anna Appulembang, ${ }^{2}$ Mohammad Zulkarnain ${ }^{2}$ \\ ${ }^{1}$ Faculty of Public Health Sriwijaya University, Jl. Palembang-Prabumulih KM 32 Ogan Ilir, 30662, \\ Indonesia \\ ${ }^{2}$ Faculty of Medicine, Universitas Sriwijaya, Jl. Srijaya Negara, Bukit Lama, Kec. Ilir Bar. I, Kota \\ Palembang, South Sumatera, 30139, Indonesia
}

\begin{abstract}
Children living in rural areas are prone to nutritional deficiencies. Low-income levels impact people's purchasing power so that the intake of most nutrients comes from plant-based foods and consumes less animal food. Nutritional intake greatly affects the development of children's cognitive function. Brain-derived neurotrophic factor (BDNF) is a group of neurotrophins that contribute greatly to the learning process and memory. This study aims to analyze the relationship between levels of BDNF with the level of intelligence in elementary school children in rural areas of Seluma Regency. This was a cross-sectional study involving 70 elementary school children aged 9-12 years were taken by multi-stage random sampling, who came from 5 districts of Seluma Regency. Blood was collected for measurement of BDNF levels, and stool samples were examined to detect intestinal parasites. The data on respondent characteristics were derived from questionnaires. Data analysis were done by using the chi-square test. The results of BDNF measurements found 31 children (44.3\%) had BDNF levels below the average $(<3342.95 \mathrm{ng} / \mathrm{mL})$. The results of measuring intelligence level found that 54 children (77.1\%) had a level of intelligence below the average. Chi-Square test results obtained $p=0.012$ with a $P R$ value of 7.538. There was a significant association between the BDNF level and intelligence level in elementary school students in the rural area. Elementary school children in rural areas with BDNF levels below the average risk of 7.538 times have below-average intelligence levels.
\end{abstract}

Keywords: Brain-derived neurotrophic factor, elementary school children, intelligence, rural areas

\begin{abstract}
ABSTRAK
anak-anak yang tinggal di daerah pedesaan rentan mengalami kekurangan zat gizi. Tingkat pendapatan yang rendah mempengaruhi daya beli masyarakat, sehingga asupan zat gizi sebagian besar berasal dari sumber nabati dan lebih sedikit mengkonsumsi sumber hewani. Asupan gizi sangat mempengaruhi perkembangan fungsi kognitif anak. Brain-derived neurotrophic factor (BDNF) adalah sekelompok neurotrofin yang berkontribusi besar pada proses pembelajaran dan memori. Penelitian ini bertujuan untuk menganalisis hubungan antara kadar BDNF dengan tingkat kecerdasan pada anak sekolah dasar di daerah pedesaan, Kabupaten Seluma. penelitian ini merupakan penelitian potong lintang dengan melibatkan 70 anak sekolah dasar usia 9-12 tahun yang berasal dari 5 kecamatan di Kabupaten Seluma. Dilakukan pengambilan darah untuk pengukuran kadar BDNF, dan pengambilan sampel feses untuk mendeteksi infeksi kecacingan. Data karakteristik responden diperoleh dari kuesioner. Semua data kemudian dianalisis menggunakan uji Chi-square. hasil pengukuran kadar BDNF didapatkan bahwa, 31 anak $(44,3 \%)$ memiliki kadar BDNF di bawah rata-rata $(<3342,95 \mathrm{ng} / \mathrm{mL})$. Hasil pengukuran tingkat kecerdasan didapatkan bahwa, 54 anak (77,1\%) memiliki tingkat kecerdasan dibawah rata-rata. Hasil uji chi-square diperoleh $\mathrm{p}=0,012$ dengan nilai $\mathrm{PR}=7,538$. terdapat hubungan yang signifikan antara kadar BDNF dan tingkat kecerdasan pada anak sekolah dasar di daerah pedesaan. Anak sekolah dasar di daerah pedesaan dengan kadar BDNF di bawah rata-rata berisiko 7,538 kali memiliki tingkat kecerdasan di bawah rata-rata.
\end{abstract}

Kata Kunci: Brain-derived neurotrophic factor, anak sekolah dasar, kecerdasan, daerah pedesaan

Correspondece Address: Rostika Flora, Faculty of Public Health Sriwijaya University, Jl. Palembang-Prabumulih KM 32 Ogan Ilir 30662, Indonesia, E-mail: rostikaflora@gmail.com 


\section{Introduction}

Brain-derived neurotrophic factor (BDNF) is is a neurotrophine involved in synapsis development, synapsis plasticity and cognitive function. ${ }^{1,2,3,4}$ BDNF is closely related to cognitive functions, including memory formation, learning process, and behavior. ${ }^{6}$ Study by Yeom et al. (2016) and Rita et al (2015) found that BDNF level in children with good nutrition status is higher than those who has lower nutrition status $(1.047 \pm 1.735 \mathrm{ng} / \mathrm{ml}$ vs $0.458 \pm 1.055 \mathrm{ng} / \mathrm{m})$, there was a significant relationship between BDNF levels and intelligence levels in elementary school children aged $5-7 .^{7,8}$

Children living in rural areas are prone to nutritional deficiencies. Low-income levels impact people's purchasing power so that the intake of most nutrients comes from plant-based foods and consumes less animal food. Nutritional intake greatly affects the development of children's cognitive function. Children with good nutritional status allow optimal cognitive development and vice versa. Children with insufficient nutritional intake will interfere with brain development, cause cognitive development to be inhibited, and ultimately lead to poor learning achievement. ${ }^{9}$

Seluma Regency is one of rural area and also one of the underdeveloped regencies in Bengkulu Province. Unhygienic environments, chronic poverty, and poor access to health services are underlying causes why children in Seluma Regency are vulnerable to worm infection and malnutrition. ${ }^{10}$ Intelligence levels may be influenced by many factors such as genes, nutrition, and environment. ${ }^{11}$ There is a significant correlation between nutritional status and cognitive functions; poor nutritional quality is correlated with low IQ levels. ${ }^{12,13}$ This study analyzes the association between BDNF levels and intelligence levels of elementary school children in rural areas, Seluma Regency.

\section{Methods}

This study was cross-sectional design conducted in April 2019. The subject of this study was 70 elementary school children aged 9-12 years old. The subject's inclusion criteria were as follows: not transfer citizens from other sub-districts selected for this study, not infected with chronic diseases, and not having a period during the study.

The subject was collected using a multi-stage random sampling technique. The sampling process was started by determining the sub-districts of the Seluma Regency with the highest malarial incidences. From the total 14 sub-districts, 5 sub-districts were selected, i.e., Lubuk Sandi, Seluma Barat, Seluma Timur, Seluma Utara, and Talo Sub-Districts. From each of these sub-districts, 14 students were selected. The total of study subjects was 70 . Blood sampling was carried out to examine BDNF levels, and stool samples were analyzed to detect intestinal parasites. Besides that, nutritional 
status and intelligence levels (IQ) were also measured. Research Ethics Committee has approved this study of Public Health Faculty, Universitas Sriwijaya based on approval decree number 78/UN9.1.10/KKE/2019.

\section{Measurement of BDNF Levels}

To measure the level of the BDNF, two milliliters of venous blood were collected from study subjects. The blood was centrifuged at the speed of $3000 \mathrm{rpm}$ for 15 minutes. The plasma portion from the centrifugation was removed and stored at $18^{\circ} \mathrm{C}$. BDNF levels were determined using the enzyme-linked immunosorbent assay (ELISA) method with Human BDNF ELISA Kit (Cat. No. EEL H0010, Elabsience; with specification: sensitivity: $18.75 \mathrm{pg} / \mathrm{mL}$, detection range: $31.25-2000$ pg/mL, specificity: This kit recognizes Human BDNF in samples, repeatability: coefficient of variation is $<10 \%$.). The levels of BDNF were calculated to find out the cut-off point based on the average level. Finally, the BDNF levels obtained from this calculation were grouped into two categories, i.e., high average and low average.

\section{Measurement of Intelligence Levels}

The measurement of intelligence levels used culture fair intelligence test (CFIT) scale 2 for children aged 8-14. This research instrument consisted of two forms, and each of which contained 4 sub-tests. Time allocated for subtest 1: series is three minutes; subtest 2: classifications are four minutes; subtest 3: matrices is three minutes; and subtest 4: conditions is 2.5 minutes. The IQ scores obtained from the scale were classified as follows: genius (scores $>170$ ); very superior (140-169); superior (120-39); high average (110-119); average (90-109); low average (80-89); borderline (70$79)$; and mentally defective $(<70)$.

\section{Measurement of Nutritional Status}

Nutritional status was assessed based on indices of height and age (H/A). The body height was measured using microtoice hung on a vertical wall 2 meters away from the horizontal floor with no carpet. The respondents stood upright on a wall with both soles attached to the floor and wore no footwear, cap, or hair accessories. The assessments of nutritional status were classified into short (Zscore -3 SD $-<-2$ SD) and normal (Z-score -2 SD - 2 SD).

\section{Determination of Intestinal Parasites}

Direct microscopy of stool samples using eosin $2 \%$ was performed to determine intestinal helminths.

\section{Statistic}


The data analysis were done using the Chi-square test in SPSS version 19.0, to examine the association between serum BDNF levels and intelligence levels.

\section{Results}

\section{Demographic characteristics}

The demographic data characteristics found in subjects based on sex and age found that most children (55.7\%) were female and aged 9-10 years old (65.7\%). The measurements of nutritional status found that $30 \%$ of children were stunted. From the clinical history of helminthiasis, $30 \%$ had ever had the infection, and microscopic examination found $31.4 \%$ of the respondents were positive with helminthiasis (Figure 1). On the other hand, the demographic characteristics of parents based on education and occupation showed that most fathers graduated from senior high school (32.9\%) and worked as farmers/labors (64.3\%). Most mothers graduated from junior high school (32.9\%) and worked as a housewife (61.4\%) (Figure 2).

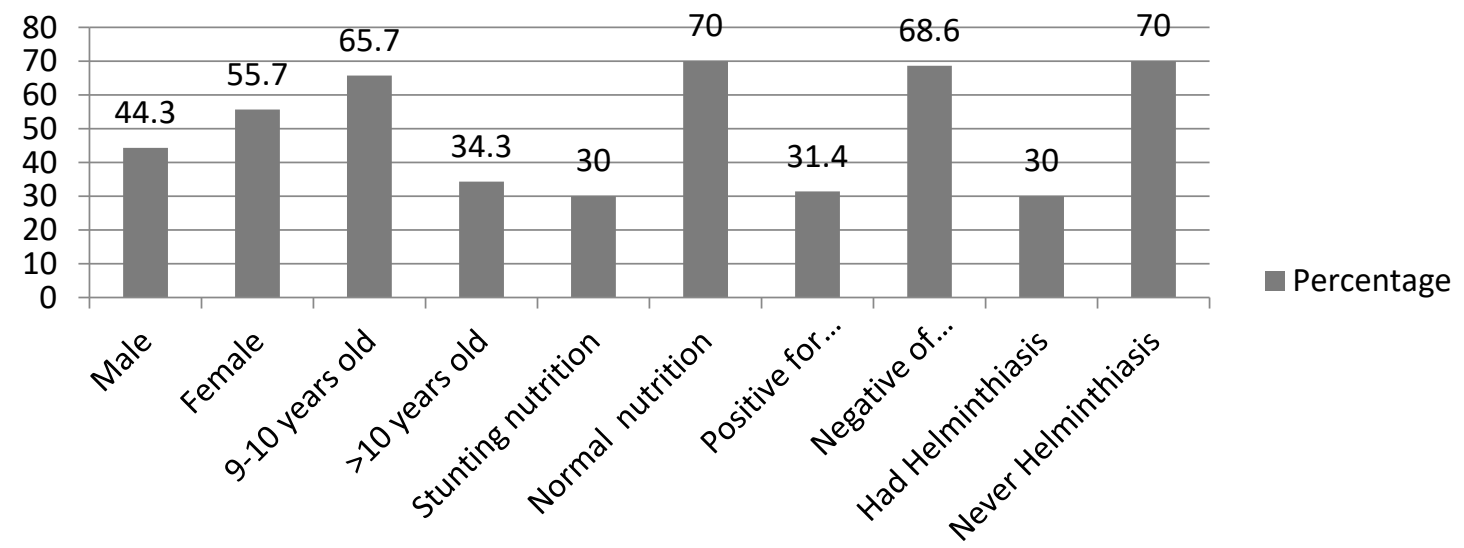

Figure 1. Frequency distribution of respondent based on sex, age, nutritional status and helminthiasis $(n=70)$ 


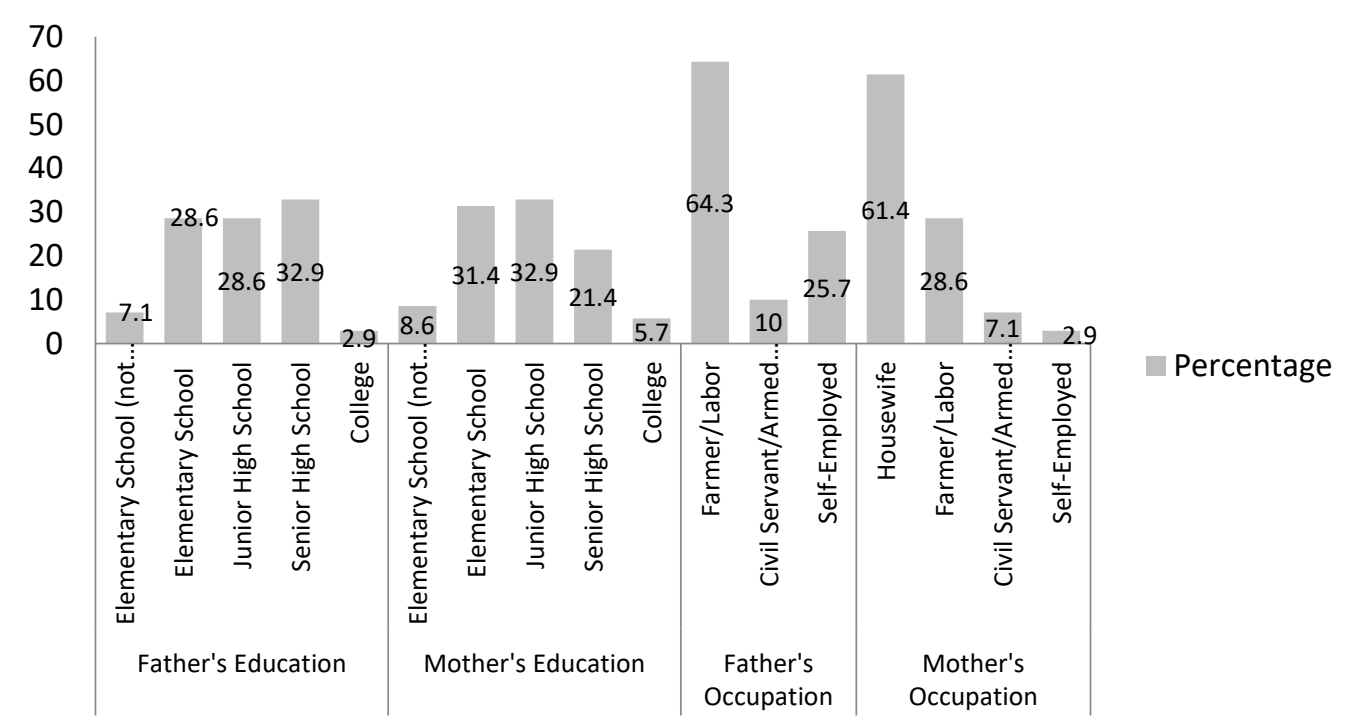

Figure 2. Frequency distribution of respondent based on parental education and occupation $(\mathbf{n}=\mathbf{7 0})$

From the measurement of serum BDNF levels as seen in Figure 3, it was found that $55.7 \%$ of children had high-average BDNF levels (> $3342.95 \mathrm{ng} / \mathrm{mL}$ ). From the measurement of intelligence levels (Figure 3), it was found that $77.1 \%$ of the children had intelligence levels in a low-average category.

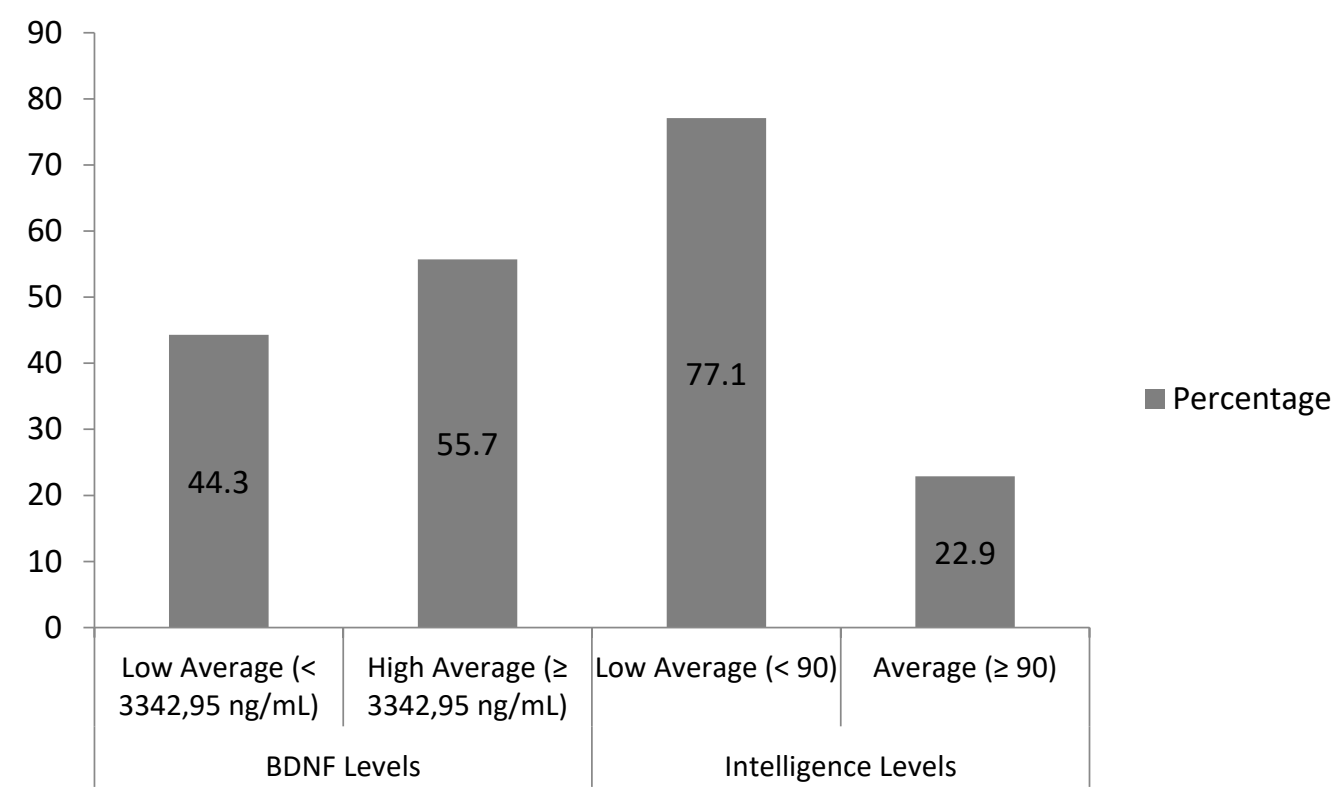

Figure 3. Frequency distribution of respondent based on average levels of BDNF serum and intelligence levels $(n=70)$ 
The chi-square test results (Table 1) indicated that children with low-average serum BDNF levels had the risk of 7.538 times to have low-average intelligence levels compared with those with highaverage serum BDNF levels.

Table 1. Association Between BDNF Levels And Intelligence Levels

\begin{tabular}{|c|c|c|c|c|}
\hline \multirow{2}{*}{ Variable } & \multicolumn{2}{|c|}{ Intelligence levels } & \multirow{2}{*}{ PR (CI) } & \multirow{2}{*}{$p$} \\
\hline & Low : n (\%) & Average : n (\%) & & \\
\hline \multicolumn{5}{|l|}{ BDNF } \\
\hline Low & 29 (41.4) & $2(2.9)$ & $\begin{array}{c}7.538 \\
(1.561-36.410)\end{array}$ & 0.012 \\
\hline High & $25(35.7)$ & $14(20)$ & & \\
\hline
\end{tabular}

\section{Discussion}

The serum BDNF levels measurement showed that $55.7 \%$ of the children had high-average BDNF levels (>3342.95 ng/mL). However, the measurement of intelligence levels found that $77.1 \%$ of the children had intelligence levels in the low-average category. This emphasized that children's intelligence levels were influenced by BDNF levels and the mother's education and parenting style.

According to research data characteristics, most mothers in this present study had lower education (72.9\%) and worked as housewives (61.4\%). Nurmaliza's study in 2018 indicated an association between a mother's education level and knowledge and nutritional status. ${ }^{14}$ Mother's knowledge levels on nutrition highly influenced their parenting style. The higher the knowledge they have, the better the food they give to their children. ${ }^{15}$ Mothers with sufficient knowledge levels have children with good nutritional status as well. ${ }^{16}$ So, it can be stated that the level of a mother's knowledge affects the intelligence levels of their children.

The results of this present study also showed that there was an association between serum BDNF levels and intelligence levels $(p=0.012)$. Children with low-average BDNF levels had a higher risk of having low-average intelligence levels than those with high-average BDNF levels. This evidence showed that the decrease of BDNF levels was correlated with the reduction of cognitive functions.

Intelligence level is a part of cognitive functions. Cognitive functions are highly influenced by histological structure maturation and the functional performance of neurons in the brain. Quality development of the neuron system in childhood will affect the adult phase's quality of cognitive functions. ${ }^{17}$

Neuron development occurs through neurogenesis, a process of generating functional neurons from precursors. ${ }^{18}$ Neurogenesis process highly depends on neurotrophin, a protein group that enforces the growth, development, plasticity, and endurance of neurons. One of the neurotrophins is 
BDNF. ${ }^{3} \mathrm{BDNF}$ is a common growth factor in the central nerve system (CNS), which is essential for the development of CNS and neuronal plasticity. ${ }^{19}$

BDNF plays a key role in memory and learning processes. ${ }^{1-5}$ Therefore, BDNF is closely related to cognitive functions such as memory formation, learning process, and behavior. ${ }^{6}$ Thus, activity-dependent BDNF expression in the hippocampus and prefrontal cortex (PFC) may contribute to cognitive and behavioral flexibility. ${ }^{21}$ Microglia promotes learning-related synapse formation through BDNF signaling to serve important physiological functions in learning and memory. ${ }^{22}$

This study's results were in line with those of Yoem et al. (2016), who stated that serum BDNF level in children aged 6-7 years is higher than in children aged 5-6 years. The serum BDNF level was negatively correlated with the Full-Scale IQ $(r=-0.39, \mathrm{p}=0.04)$ and Verbal IQ $(r=-0.50$, $\mathrm{p}=0.01)$, but not with the Performance IQ $(\mathrm{r}=-0.12, \mathrm{p}=0.56)^{7}$. Another similar study by Rita et al. found that children's motoric development is better on those with average BDNF levels of 1.083 $\pm 1.722 \mathrm{ng} / \mathrm{mL}$ compared with those with BDNF levels of $0.031 \pm 0,105 \mathrm{ng} / \mathrm{mL}$. The increase of cognitive functions is correlated with the increase of motor skills and BDNF as a mediator learning motorik related to plasticity. ${ }^{8}$

\section{Conclusion}

In conclusion, There was a significant association between the BDNF level and intelligence level in elementary school students in the rural area. Elementary school children living in rural areas with low-average BDNF levels had a risk of 7.538 times to have low-average intelligence levels.

\section{Acknowledgment}

The fund for this research was from the Ministry of Research and Technology and Higher Education of the 2019 Basic Research grant scheme, No. Contract 0125.07 / UN9 / SB3.LP2M.PT / 2019 with Dr. Rostika Flora as the Chief Researcher.

\section{Funding}

The Grants of Ministry Research Technology and Higher Education Basic Research 2019.

\section{Conflicts of Interest}

There is no conflicts of interest in this study.

\section{References}

1. Tyler WJ, Alonso M, Bramham CR, Pozzo-Miller LD. From acquisition to consolidation: on the role of brain-derived neurotrophic factor signaling in hippocampal-dependent learning. Learn Mem. 2002;9(5):224-237. 
2. Yamada K, Mizuno M, Nabeshima T. Role for brain-derived neurotrophic factor in learning and memory. Life Sci. 2002;70(7):735-744. doi:https://doi.org/10.1016/S00243205(01)01461-8

3. Binder DK, Scharfman HE. Brain-derived neurotrophic factor. Growth Factors. 2004;22(3):123-131. doi:10.1080/08977190410001723308

4. Rattiner LM, Davis M, Ressler KJ. Brain-Derived Neurotrophic Factor in AmygdalaDependent Learning. Neurosci. 2005;11(4):323-333. doi:10.1177/1073858404272255

5. Cunha C, Brambilla R, Thomas K. A simple role for BDNF in learning and memory . Front Mol Neurosci . 2010;3:1.

https://www.frontiersin.org/article/10.3389/neuro.02.001.2010.

6. Effect THE, Physical OF, On A, Brain THE. Review article The Effect Of Physical Activity On The Brain Derived. Physiology. 2010;(16):533-541.

7. Yeom C-W, Bhang S-Y. PM348. Association of peripheral BDNF level with cognition, attention and behavior in preschool children. Int J Neuropsychopharmacol. 2016;19(Suppl 1):27. doi:10.1093/ijnp/pyw041.348

8. Rita, As'ad S, Hadju V, Tammasse J. The Correlation between Brain Derived Neurotrophic Factor (BDNF) Level and Motor Development of Children Aged Under 2 Years in Timor Tengah Selatan Nusa Tenggara Timur. IJSBAR. 2015;23(1):164-72.

9. Almatsier S. Prinsip Dasar Ilmu Gizi, Jakarta, Penerbit PT. Gramedia Pustaka Utama. 2004.

10. Dinas Kesehatan Provinsi Bengkulu. Profil Kesehatan Bengkulu Tahun 2017. Bengkulu: Dinas Kesehatan Provinsi Bengkulu; 2018.

11. Boeree GC. Intelligence and IQ. Shippensburg University. 2003.

12. McWilliams M. Nutrition for the Growing Years. California: Plycon Press, Inc; 1993.

13. Sudargo T, Huriyati E, Safitri L, Irwanti W, Nugraheni SA. Hubungan Antara Status Gizi, Anemia, Status Infeksi, Dan Asupan Zat Gizi Dengan Fungsi Kognitif Pada Anak Sekolah Dasar Di Daerah Endemik Gaki. Gizi Indones. 2012;35(2).

14. Nurmaliza N, Herlina S. Hubungan Pengetahuan dan Pendidikan Ibu terhadap Status Gizi Balita. J Kesmas Asclepius. 2019;1(2):106-115.

15. Subekti S, Yulia C. Pengetahuan Gizi dan Pola Asuh Ibu Anak Balita Gizi Kurang di Kelurahan Pasteur Kecamatan Sukajadi Bandung. Invotec. 2012;8(1).

16. Susanti I, Pambayun R, Febry F. Gambaran Faktor-faktor yang Mempengaruhi Status Gizi Anak Umur 2-5 Tahun pada Keluarga Petani di Desa Pelangki Kecamatan Muaradua Kabupaten OKU Selatan. J Ilmu Kesehat Masy. 2012;3(2).

17. Morris, Terry Mc. PT A and M. Exercise and Cognitive Function. 1st Ed. USA: Jhon Wiley \& Sons, Ltd: (Terry Mc Morris PT and MA, ed.); 2009.

18. Ming G, Song H. Adult neurogenesis in the mammalian brain: significant answers and 
significant questions. Neuron. 2011;70(4):687-702.

19. Autry AE, Monteggia LM. Brain-derived neurotrophic factor and neuropsychiatric disorders. Pharmacol Rev. 2012;64(2):238-258.

20. Zoladz JA, Pilc A. The effect of physical activity on the brain derived neurotrophic factor: From animal to human studies. J Physiol Pharmacol. 2010;61(5):533-541.

21. Sakata K, Martinowich K, Woo NH, et al. Role of activity-dependent BDNF expression in hippocampal-prefrontal cortical regulation of behavioral perseverance. Proc Natl Acad Sci U S A. 2013;110(37):15103-15108. doi:10.1073/pnas.1222872110

22. Parkhurst CN, Yang G, Ninan I, Savas JN. Yates 3rd, JR, Lafaille, JJ, Hempstead, BL, Littman, DR, Gan, WB, 2013. Microglia promote learning-dependent synapse formation through brain-derived neurotrophic factor. Cell. 155(7):1596-1609. 